\title{
Transition to A True Currency: Impact of COVID-19 on The World Currency System
}

\author{
Indra Fajar Alamsyah ${ }^{*}$, Juliana Juliana ${ }^{2}$ \\ ${ }^{1}$ Kulliyyah of Economics and Management Sciences, International Islamic University Malaysia, Kuala Lumpur, Malaysia \\ ${ }^{2}$ Department of Islamic Economics and Finance, Universitas Pendidikan Indonesia, Bandung, Indonesia
}

\section{ARTICLE INFO}

\author{
Keywords \\ COVID-19, Currency System, \\ Islamic Currency, \\ Macroeconomics \\ *Correspondence \\ indrafajaralamsyah@gmail.com
}

\author{
Article History \\ Received 22 January 2021 \\ Accepted 28 April 2021 \\ Published online 24 June 2021
}

\section{ABSTRACT}

The purpose of this paper is to manifest the unrefined design of the transition of the currency system from centralized fiat money based on the US Dollar to the real currency system that relies on the precious metals-based currency after reviewing the rapid changes from the COVID-19 phenomenon to various sectors of life, including the currency system. This paper used qualitative research with a historical analysis approach or historiography that deals with precious metals-based currency in the pastime, and it is used to produce relevant analyses for the future. First, states that prefer to transition to a precious metals-based currency ought to combine them in a single political institution that can provide a strong bargaining position in politics. Second, they have to withdraw gold reserves from the major central banks by making a trade balance surplus paid only in precious metals. Third, at this transitional stage, the use of oil reserves as a political economy of energy to withdraw gold reserves at the major central banks and the issuance of money is temporary until the state is fully stable and a new wave of gold reserves begin to enter. The underlying study will provide a comprehensive analysis of the currency system scheme in this modern era. Previous works have only focused on the superior aspects of the precious metals-based system and criticisms of the fiat money system, without detailing the steps to supersede the fiat money-based system. This paper used qualitative research with a historical analysis approach or historiography. It attempted to fill this glaring gap and expected to produce a study for implementation within the state scope.

\section{INTRODUCTION}

A new approach is therefore needed for contemplating the link between Covid-19 and changes in the currency system. Since the Covid-19 outbreak was declared a global health emergency on January 30,2020, because it spread quickly to various parts of the world, the Covid-19 outbreak has also rapidly paralyzed the economic sector (Bouhali, Dhahbani \& Dinar, 2020; Gibson \& Olivia, 2020). Various discussions of the economic crisis have been widely discussed regarding the impact of this outbreak. One thing is rarely discussed, namely the connection with the monetary approach (Bresser-Pereira, 2020). A series of recent studies have indicated there is a need for an in-depth study of this issue. Bambrough (2020) and Pinshi (2020) argue there is something wrong with the way people are using money today and are increasingly aware when the Covid-19 crisis hits. Fluctuations in world currencies are increasingly volatile and harm international trade. From an Indonesian perspective, macro data shows that during this pandemic, the rupiah exchange rate weakened 0.42 percent to a level of Rp 15,640 per US dollar in the spot market trading in mid-April. Analysts said the Indonesian rupiah weakened in line with market concerns about the increasing economic impact of the Covid-19 pandemic. From a broader perspective, the majority of Asian currencies also weakened against the US dollar. As identified by Moss (2020), the Japanese yen fell 0.32 percent, 0.29 percent for the Singapore dollar, 0.14 per cent for the Taiwan dollar, 0.93 per cent for the South Korean won, 0.3 per cent for the Philippine peso, 0.56 per cent for the Indian rupee, 0.12 percent for the Chinese yuan, and 0.84 per cent for the Malaysian ringgit.

Similarly, Keoun (2020) stated that the decline in the exchange rates of each of these countries resulted from market concerns about the economic impact of the spread of the Covid-19 pandemic. Market concerns arose from the US drop in retail sales data, which reached minus 8.7 percent in March 2020 (Yuning, 2020). Even though some of the currencies of these countries tended to strengthen, the market is also still watching the development of the crisis (the spread of the coronavirus), such as in advance economist Krugman (1995) said since long ago. This means that it goes up or down, weakens or strengthens as soon as it fluctuates following the crisis. This outbreak has opened our eyes for the umpteenth time about the fragility of the wealth exchange unit created by the monetary system we are currently living in, regardless of the form of the crisis. Therefore it is not surprising when 
Michie (2020) proposes a total change in creating a wealth exchange unit to look to the future after Covid-19. Lewis (2020) highlighted that in the future, the US dollar-based fiat money system would collapse, destroying the world, and according to Michie (2020) the presence of the Covid-19 outbreak seems to accelerate the process.

\section{RESEARCH METHODS}

The method used in this study is the historical method or historiography. The historical method is an imaginative reconstruction of the past picture of historical events critically and analytically based on evidence and data from the past, called historical sources (Blaug, 1990). Researchers use this method because the data and facts needed as a source in writing this study come from the past, particularly about the use of currency systems based on precious metals that have been practiced. The data collection techniques used are through library research which is carried out by reviewing multiple literature sources that can assist the authors in solving the problems being studied.

\section{RESULTS AND DISCUSSIONS}

\subsection{The Paradox of Fiat Money}

Meanwhile, the world was still followed the standard gold money was backed up by gold in the pastime, big holes due to the damage to this fiat money are hard to scrutinize (D'Arista, 2009; Palley, 2014). However, this time has long been abandoned by the world economy since 1931 when the United States government stopped allowing its citizens to convert paper currency into gold deposits (Cohen, 2006; Bowles \& Wang, 2008). Currently, the circulating fiat money has become a medium of exchange because the government has designated it as a medium of exchange. If the government revokes its decision and uses the money of another type, the paper money will have no value at all (Palley, 2014; Bjerg, 2014). The issuance of fiat money creates new purchasing power from something that is not valuable because money has no price but reflects the price of all goods. This is where injustice arises. Hence, something that is not valuable (fiat money) can be exchanged for goods (something of value) (Bryan \& Rafferty, 2013). Another essential point, based on the ideas of McMurtry (2013) in economic terms, money does not provide a direct use (indirect utility function) but can be used to buy valuable goods. Fiat money also provides unfair benefits concerning its issuance, known as seigniorage, videlicet the return on the issuance of the money for the money issuing authority.

A more comprehensive description can be found in Wray (2012). History has proven that the danger of fiat money (notes and coins) whose intrinsic value is much lower than its face value is one of the causes of the economic crisis. According to Nezhad (2004) to achieve monetary stability, it must be supported by a stable currency system, which only gold and silver currencies have. Subsequently, Norrlof (2014) argues this is because the intrinsic value (gold-silver) equal to its nominal value is a solid character to stabilize the economy. Thus, the difference in fiat money's intrinsic and nominal values caused an economic bubble and economic crisis. This is because almost all fiat currency systems experience uncontrollable inflation (Rueff, 1972; Krugman, 1995; Wray, 2012).

\subsection{Fall of the Dollar}

The US dollar has long been the world's global currency, for decades, the use of the dollar has been dominant in international trade activity. This provides tremendous benefits to the United States financial system (Stokes, 2013; Gärtner, 2016). Regarding the dollar, the United States has excellent control over the world. Currently, more than 60 percent of all worlds' foreign currency reserves are denominated in dollars, and lately, there have been significant changes to this composition (Nye, 2002). For example, as can be seen in Aslund (2020), some oil-producing countries have also started selling oil in currencies other than dollars, threatening the petrodollar system that has been running for nearly four decades. Large international institutions, such as the United Nations and the IMF, have even issued official reports on the need to establish a new global currency system to replace the dollar (Beggs, 2017). Like it or not, the dollar's domination as the world's currency is definitely under threat. In the same way, over the past few years, China and other developing countries, such as Russia, have been quietly making deals to move away from the US dollar in international trade. Thus, the US dollar supremacy is not as tough as most Americans believe (Sgambati, 2020).

The US move to use the dollar as a tool to pressure other countries is currently sparking an international reaction to reduce its dependence on the dollar, as have Russia and China, two of the United States' international rivals (Maldonaldo, Ribeiro \& Tourinho, 2019). After several years of negotiations between Russia and China to set aside US dollars as a medium of trade exchange, the two countries agreed to reduce the use of the dollar in the first quarter of 2020 to less than 50 percent for the first time. Previously, in 2016, the dollar accounted for more than 90 percent of the currency of trade of Russia and China. Based on statistical data, 54 percent of the two countries' non-dollar trade is currently denominated in yuan, euro, and ruble in the proportion of 17 percent for Chinese yuan, 30 percent for European's euro, and 7 percent for Russian's ruble (Trunkos, 2020).

Prior research suggests that the U.S exploits the dependence of companies and banks and the international monetary system on the dollar to force other countries to comply with its demands or prevent action that is not Washington's wishes. The US-led trade war scheme with China counters Washington's move since 2018 to counter US financial instruments, particularly the dollar, as well as the imposition of broad sanctions against Russia. As a result, Beijing and Moscow decided to take practical steps to reduce the economy's dependence and the financial sector on the US dollar (Plakandaras, Gupta, Gil-Alana \& Wohar 2018; Antonopoulos \& Cottle, 2018). In January 2020, Russian Foreign Minister Sergei Lavrov announced that Moscow was pursuing a policy of gradually reducing the dollar's role and replacing it with the local currency (Trunkos, 2020). Moscow and Beijing believe that using the dollar by the US to attack other countries, although it can achieve Washington's goals in the short term, its implementation in the long term will be detrimental to the United States (Malkin, 2019). It seems that the move by the coalition of Russia and China as the two most important political and economic powers in the world will encourage other countries to follow the same pattern, thereby significantly reducing the role of the dollar in the global monetary system (Maldonaldo, Ribeiro \& Tourinho, 2019).

Overall, The US dollar tends to weaken during the Covid-19 episode (Lin, 2020). According to Roubini (2020) the United States continues to monetize large budget deficits leading to large external deficits. A surge in inflation could eventually drive down the dollar and weaken its appeal as a reserve currency, given the current mix of US economic policies, it is a growing risk. Another risk is the loss of the United States' geopolitical hegemony, which is one of the main reasons why so many countries use the dollar in the first place. History records that the hegemon currency naturally became a global reserve currency. The same was true of Spain 
in the $16^{\text {th }}$ century, the Netherlands in the $17^{\text {th }}$ century, France in the $18^{\text {th }}$ century, and Great Britain in the 19th century (Sakaguchi, 2020).

\subsection{Islamic Currency System as A True Currency}

In Arabic terms, money is usually known as al-nuqūd (Al-Maqrīzī, 1913). However, historically the Arabs did not have their own currency which was used as a medium of exchange with other nations. They are familiar with currency when conducting trade transactions outside the Arabian Peninsula. Meanwhile, they returned from trading. They brought gold and silver coins. The coins were circulating in areas controlled by the Roman and Persian Empires (Al-Dhahabī, 1934; Abdullah, 2016). As well as in the same way, Al-Dhahabi (1934) stated that during Islam came, the system of economic transactions that was already running in society with gold and silver coins from Rome and Persia - was recognized by the Prophet (peace be upon him). Consequently, in this early period, the Islamic state used Persian silver dirham and Roman gold dinar in their original forms, without any change of form. The person who first issued the dirham and dinar to be enforced in an Islamic state was the Umayyad Caliph, Abdul Malik bin Marwan, in $74 \mathrm{H}$. for an Islamic state. However, even though the Prophet (peace be upon him) never made a special currency for an Islamic state, the scholars explained that only currency based on precious metals (gold-silver) was legal as a medium of exchange in an Islamic state (Al-Māwardī, 1938; Ibn Khaldūn, 1917; Meera, 2002; Meera \& Larbani, 2004).

Seminal contributions have been made by Ibn Khaldūn (1917) he stated Allah created two precious metals (gold and silver) as the justice for every treasure. And justice must come from objects that can last a long time because of continuous needs. The type of property that lasts the longest is mining goods. Therefore currency in classical times was made of gold, silver, and copper because mining goods are believed to last a long time and are not easily damaged (Al-Shustari, 1964; Yaacob, 2012). Specifically, Al-Maqrīzì (1913) stated that currencies could be accepted as a standard of value, according to law, logic, and tradition, only consist of gold and silver. In short, the currency that uses anything other than gold and silver is considered unworthy of being called currency (Arif \& Shabbir, 2019).

Apart from this, the use of money (gold-silver) in addition to seeing the value aspect, there are also legal aspects seen in fiqh Islam (Islamic jurisprudence) (Al-Balādhurī, 1956). Al-Nabhānī (1990) explained five reasons that the application of the monetary system based on precious metals is the implementation of sharia law: (1) When Islam prohibits hoarding of assets (kanz al-māl), Islam only specifies the prohibition of hoarding gold and silver. As for collecting other than that, it is not called kanz al-māl, but ihtikār (Al-Bāqī, 1994). Therefore this prohibition is aimed at the medium of exchange. (2) Islam has linked gold and silver with standard and immutable laws. Whereas Islam stipulates diyat (fines), Islam has specified it with a certain measure in the form of gold (Al-Shawkani, 1987). (3) Prophet (peace be upon him) The Prophet (peace be upon him) established gold and silver as money, subsequently strict made gold and silver as the standard of money in the form of 'üqyah, dirham, dāniq, qirāth, mithqāl and dinar. All of this is well used by the people and the Prophet (peace be upon him) kept it quiet (Ibn Kathir, 1995). (4) When Allah obliges zakāt for money, Allah has obliged the zakāt for gold and silver. Thereupon Allah determines the nisāb of the zakāt with the nisāb of gold and silver (Abū 'Ubaid, 1989). The existence of zakāt for money in the form of gold and silver has determined that the money is in the form of gold and silver (Al-Māwardī, 1999). (5) The laws regarding currency exchanges that occur in money transactions are carried out only in gold and silver. All transactions in financial form which are stated in Islam are only stated in gold and silver (Al-Qarāshī, 1984; Al-Shīrāzi, 1995; Al-Qaradāwī, 1994; Al-Nawawī, 2003). All in all these points, in Islamic law, money is seen as something that has been explained by the sharia law (Ibn Al-Jawzī, 1932). In other words, money is not something that falls into the category of results of negotiation and masūrah (deliberation) (Ibn Manzūr, 1955). Nor is money simply something that is demanded by economic life or monetary life. However, in terms of its position as a unit of money, also in terms of its type, money is the result of sharia law stipulations (Al-Nabhānī, 1990).

\subsection{The Role of the State in Restoring the Gold-Silver Standard}

Since the United States released its dollar currency peg against gold in 1971, its currency has automatically adopted the fiat money system, the dollar printed by the Central Bank that is not guaranteed and supported by gold. The public is legally forced to make dollar bills as valuable goods, according to the numbers written on the dollar banknotes. The system was problematic from the start Armed with an understanding of the damage to exchange systems like this, some parties have taken the initiative to exit and switch to other systems, including a gold monetary system or using a gold-backed monetary system.

In Indonesia, Saidi (2006) is well known for initiating the use of dinar and dirham as mediums of exchange in society. He explained the application at the practical level of transactions using the dinar-dirham in several regions in Indonesia and the detailed implementation mechanism. However, over time we can see there is a large gap that has been overlooked on the way of implementing transactions with dinars such as these; scilicet not using state instruments to implement the use of these dinars in the community, for the sake of what happened was only a community-based initiative (groups) that made their own use of the dinar-dirham as a unit of exchange in society. At this stage, a gap will appear that cannot be covered by these groups in implementing the use of the dinar-dirham, because this domain is the domain that should be carried out by the state, not the domain of groups in society. At this point, we will realize how much we need a state that is willing to implement this system. One of the conditions is, by all means, a state that has sufficient gold reserves. Table 1 shows the 10 countries with the most gold reserves in the world.

Table 1. 10 Countries with the highest gold reserves

\begin{tabular}{ll}
\hline Countries & Gold Reserves \\
\hline United States & 8,133.5 tonnes \\
Germany & $3,366.5$ tonnes \\
Italy & $2,451.8$ tonnes \\
France & $2,436.0$ tonnes \\
Russia & $2,279.2$ tonnes \\
China & $1,948.3$ tonnes \\
Switzerland & $1,040.0$ tonnes \\
Japan & 765.2 tonnes \\
India & 635 tonnes \\
Netherlands & 612.5 tonnes \\
\hline urce: $I M F-$ Gold reserves as of January 2020
\end{tabular}

www.jkpis.com 
Table 1 shows that the countries that have the most mathematical opportunities to apply the gold system as currency are these countries. But in fact, almost all of these countries are big capitalist countries that do not have a predilection for implementing a gold-silver system. In the monetary terms known as seigniorage, the net income is obtained from the issuance of currency. This means that any printing of paper money that is not backed up by gold will generate a difference in profit for those who issue it, and this is what great benefits the big capitalist states whose currencies are used as the standard for economic transactions in the world. This domination is not accidental. It is a grand design imposed on the world monetary system as a whole. In fact, it is reasonable for these countries to disallowance change the unit of exchange to the precious metals standard.

In Table 2, there is a row of Muslim countries with the largest gold reserves, which are included in the top 25 countries with the most gold reserves. Furthermore, in total, there are only six countries on the list. This means that the amount of gold owned by these Muslim countries is actually not sufficient to issue gold either for their respective countries or for the unity of Muslim countries today. If the stock of gold or silver in the Central Bank is insufficient, the alternative is to get gold by buying from the international gold market or central banks of developed countries. Muslim countries must diversify their foreign exchange reserves by converting foreign exchange into gold and silver reserves.

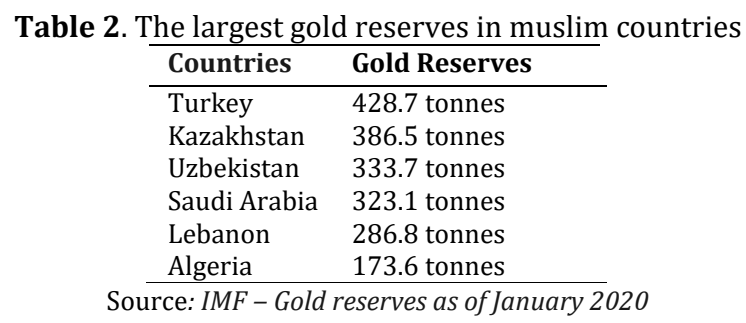

\subsection{The New Superpower Political Institution}

In addition, Muslim countries must also force their trade to balance surplus with developed countries to be paid only in gold and silver commodities. This step will certainly not run smoothly and easily, because the big capitalist countries that are accustomed to benefiting from the current system do not want their economic and trade domination to be shifted. This is where we see the important points of the unification of Muslim countries into one superpower country, a single political institution that will have a different political bargaining position compared to each moving Muslim country. With the potential of the population, the advantage of geographical location, the abundance of natural resources, and the great potential of the military, this political institution can instantly change the constellation of trade and political economy. This step to unify Muslim countries can release its link to the US dollar, change the country's foreign exchange reserves into gold and silver, and abandon various trade agreements that are forced by capitalist countries on behalf of the WTO, forcing capitalist countries to pay their international trade balance surplus with gold and silver commodities. This is sufficient to overthrow the domination of the existing capitalist monetary system.

\subsection{Alternative Transition Process through Energy Politics}

In fact, it turns out that the strategic steps taken are still ineffective. Another alternative although, temporary in nature, is to make the oil reserve support for the issuance of currencies and a powerful weapon against the resistance of developed countries very dependent on petroleum. The oil reserve of Muslim countries is currently possible to become the mainstay of support for the issuance of currency because of its large amount and can back up trade and economic transactions in various Muslim countries. This means there is no oil export to capitalist countries, and those capitalist countries want petroleum from Muslim countries. They have to pay only for gold and silver. If they refuse, the energy crisis and industrial stagnation will soon destroy their civilization. A small example was in the 1970s when OPEC boycotted oil sales to Western countries.

History records in 1973, OPEC had brought the US economy and other Western industrialized countries to their knees by imposing an oil embargo in protest of Western support for Israel. The embargo rocked the economies of industrialized countries as oil supplies fell drastically and oil prices soared. In Germany, from November 25, 1973, a driving ban was forced to apply, which became the country's first "car-free day." The OPEC move led to deep recessions in Western industrialized nations. After several months of tough negotiations, the embargo was later lifted. But OPEC's prestige as a fearsome force looms over the West. At that time, the unity of the countries was limited to the interests of the oil trade, not yet touching the aspect of state ideology. So that when Muslim countries now combine their countries on the same Islamic ideology, it can provide a bigger 'shock' and can end the domination of capitalism.

\section{CONCLUSION}

As stated in the introduction, our main aim was to dissect the unrefined design of the transition of the currency system in total change. The total change in the currency system from the basis of fiat money to dinar-dirham will take place perfectly if several points are met, particularly, the Islamic currency system based on the issuance of the dinar and dirham (which is supported by gold or silver) requires the application of the total Islamic system in the unification of Muslim countries in the form of a single political institution. Furthermore, the Islamic monetary system only runs and operates in real sectors of the economy and trade. This will guarantee the benefits in the function of financial, monetary, and economic stability. However, apart from paying attention to the beneficial functions of implementing the gold system regarding these benefits, some things are far more critical for Muslims. Consequently, it is inevitable when various problems and damages arise from capitalism's implementation, especially fiat money in the currency system. It is one more proof that when humans turn away from Allah's laws, the damage will arise. In these moments of crisis is Allah's way of warning people always to be aware and hurry to call for the straight path that only exists in the Islamic system born from the Creator of the Universe. 


\section{References}

Abdullah, A. (2016). An Islamic monetary theory of value and equation of exchange: evidence from Egypt (696-1517). Humanomics, 32(2), 121-150.

Abū 'Ubaid. (1989). Kitāb Al-Amwāl. Beirut: Dār al-Surūq.

Al-Balādhurī, A. (1956). Futūh Al-buldān. Cairo: Alkutobu Alarabia.

Al-Bāqī. (1994). Mu'jam Mufahras li Al-Fāz Al-Qurān Al-Karīm. Cairo: Dar al Hadith.

Al-Dhahabī. (1934). Tahriru al-Dirham wa al-Dinar. Cairo: Dar-al Tabaa.

Al-Maqrīzī. (1913). al-Nuqūd. Cairo: Daru Ehia Aluloom.

Al-Māwardī. (1938). al-Ahkām al-Sultaniyya. Beirut: Daru Altabaa.

Al-Māwardī. (1999). Al-Hawī al-Kabīr. Beirut: Dār al-Kutub al-'Ilmiyah.

Al-Nabhānī, T. (1990). Nidhām al-Iqtisādi fì al-Islām. Beirut: Dar al Ummah.

Al-Nawawī. (2003). Al-Majmü' Syarh Al-Muhadhdhab. Jeddah: Maktabah Al-Irshād.

Al-Qaradāwī, Y. (1994). Fiqh Al-Zakāt. Cairo: Maktabah Wahbah.

Al-Qarāshī. (1984). Kitāb Al-Kharāj. Cairo: Al-Matba'ah AsSalafiyyah.

Al-Shawkani. (1987). Nayl al-Awtar Sharh Muntaqa al-Akhbar, Vol. 7. Cairo: Maktabah Dār al-Turath.

Al-Shīrāzi. (1995). Al-Muhadhdhab. Beirut : Dār al-Kutub al-'Ilmiyah.

Al-Shustari. (1964). Tārīkh Miqyāsāt dār Asr Hukūmat Islāmī. Tehran: Chup Alrahim.

Antonopoulos, P., \& Cottle, D. (2018). Venezuela's 2017 Crisis: A Failed Bolivarian Experiment or a Legitimate Claim of US Imperialism?. Critique: Journal of Socialist Theory, 46(1), 49-64.

Arif, A., \& Shabbir, M. S. (2019). Common currency for Islamic countries: is it viable?. Transnational Corporations Review, 11(3), 222-234,

Aslund, A. (2020). Responses to the COVID-19 crisis in Russia, Ukraine, and Belarus. Eurasian Geography and Economics, DOI: 10.1080/15387216.2020.1778499

Bambrough, B. (2020, April 6). The Future of Monetary Policy is Asian. Retrieved from Forbes: https://www.forbes.com/sites/billybambrough/2020/04/06/the-coronavirus-covid-19-crisis-has-changed-money-forever/

Beggs, M. (2017). The State as a Creature of Money. New Political Economy, 22(5), 463-477.

Bjerg, O. (2014). Making Money: The Philosophy of Crisis Capitalism. London: Verso.

Blaug, M. (1990). On the historiography of economics. Journal of the History of Economic Thought, 12(1), 27-37.

Bouhali, H., Dhahbani, A., \& Dinar, B. (2020). Sustainability of basket peg choices in the post-COVID-19 era: new evidence from Morocco \& Tunisia. Macroeconomics and Finance in Emerging Market Economies, 1-20.

Bowles, P., \& Wang, B. (2008). The rocky road ahead: China, the US and the future of the dollar. Review of International Political Economy, 15(3), 335-353.

Bresser-Pereira, L. C. (2020). Financing COVID-19, Inflation and the Fiscal Constraint. Forum for Social Economics, 1-17.

Bryan, D. \& Rafferty, M. (2013). Fundamental value: a category in transformation. Economy and Society, 42(1), 130-153.

Cohen, B. J. (2006). The Macrofoundations of Monetary Power, in D. Andrews (ed.) International Monetary Power, Ithaca: Cornell University Press, 31-50.

D’Arista, J. (2009). The Evolving International Monetary System. Cambridge Journal of Economics, 33(1), 633-652.

Gärtner, M. (2016). Macroeconomics (5 ${ }^{\text {th }}$ Edition). London, UK: Pearson.

Gibson, J., \& Olivia, S. (2020). Direct and Indirect Effects of Covid-19 On Life Expectancy and Poverty in Indonesia. Bulletin of Indonesian Economic Studies. 56(3), 325-344.

Ibn Al-Jawzī. (1932). Al-Muntazam fì Tārīkh Al-Mulūk wa'l-Umam. Cairo: Matba'at al Adab.

Ibn Kathir. (1995). Al-Bidayāh wa Al-Nihāyah, Vol. 9. Cairo: Dār Ibn Kathir Li-Tibāt.

Ibn Khaldūn, A. M. (1917). Muqaddimat. Cairo: Ketabu Alshabab.

Ibn Manzūr. (1955). Lisān Al-'Arab. Vol. 15. Beirut: Dar al-Sadir.

Keoun, B. (2020, March 27). Story from Markets After Coronavirus 'War,' Bretton Woods-Style Shakeup Could Dethrone the Dollar. Retrieved from Coindesk: https://www.coindesk.com/after-coronavirus-war-bretton-woods-style-shakeup-could-dethronethe-dollar

Krugman, P. (1995). Currencies and Crises. Cambridge, MA: MIT Press.

Lewis, N. (2020, March 27). What If We Had A Gold Standard System, Right Now? Retrieved from Forbes: https://www.forbes.com/sites/nathanlewis/2020/03/27/what-if-we-had-a-gold-standard-right-now/?sh=7dd14d2a3e58

Lin, J. Y. (2020). China's economic outlook against the backdrop of the COVID-19 pandemic and US-China tensions. Journal of Chinese Economic and Business Studies, DOI: 10.1080/14765284.2020.1854024

Maldonaldo, W. L., Ribeiro, J., \& Tourinho, O. A. F. (2019). Testing Four Types of Bubbles in BRICS Exchange Rates. Emerging Markets Finance and Trade, DOI: 10.1080/1540496X.2019.1603542

Malkin, A. (2019). Challenging the liberal international order by chipping away at US Structural power: China's state-guided investment in technology and finance in Russia. Cambridge Review of International Affairs, DOI: 10.1080/09557571.2019.1642300

McMurtry, J. (2013). The Cancer Stage of Capitalism, 2nd ed. Halifax: Pluto Press.

Meera, A.K.M. (2002). The Islamic Gold Dinar. Petaling Jaya: Pelanduk Publications.

Meera, A.K.M. \& Larbani, M. (2004). The gold dinar: the next component in Islamic economics, banking and finance. Review of Islamic Economics, 8(1), 5-34

Michie, J. (2020). The covid-19 crisis - and the future of the economy and economics. International Review of Applied Economics, 14.

Moss, D. (2020, August 24). There's No Winning the Coronavirus Recovery. Retrieved from Bloomberg: https://www.bloomberg.com/opinion/articles/2020-08-23/coronavirus-malaysia-s-economy-shows-doing-the-right-thingsdidn-t-help

Nezhad, Z. (2004). A Brief History of Money in Islam and Estimating the Value of Dirham and Dinar. Review of Islamic Economics, $8(2), 51-65$.

Norrlof, C. (2014). Dollar hegemony: A power analysis. Review of International Political Economy, 21(5), 1042-1070.

Nye, J. S. (2002). The Paradox of American Power: Why the World's Only Superpower Can't Go it Alone. Oxford: Oxford University Press. 
Palley, T. (2014). Money, Fiscal Policy, and Interest Rates: A Critique of Modern Monetary Theory. Review of Political Economy, 27(1), 1-23.

Pinshi, C. P. (2020). Monetary Policy, Uncertainty and COVID-19. Journal of Applied Economic Sciences, 579-593.

Plakandaras, V., Gupta, R., Gil-Alana, L. A., \& Wohar, M. E. (2018). Are BRICS exchange rates chaotic? Applied Economics Letters, DOI: $10.1080 / 13504851.2018 .1537473$

Roubini, N. (2020, August, 25). Is this the end of the road for dollar dominance? Retrieved from The Guardian: https://www.theguardian.com/business/2020/aug/25/is-this-the-end-of-the-road-for-dollar-dominance

Rueff, J. (1972). The Monetary Sin of the West. New York: Macmillan.

Sakaguchi, A. (2020). On the Institutional Theory of Money: Learning from J. R. Commons' Institutional Economics. Journal of Economic Issues, 54(4), 975-986.

Saidi, Z. (2006). The Implementation of The Islamic Gold Dinar Economy: The Indonesian Experience. In Ahmed Kameel Mydin Meera (ed.). (2009). Real Money: Money Payment Systems from an Islamic Perspective. Kuala Lumpur: IIUM Press.

Sgambati, S. (2020). Historicizing the money of account: a critique of the nominalist ontology of money. Journal of Post Keynesian Economics, DOI: 10.1080/01603477.2020.1788396

Stokes, D. (2013). 'Achilles' Deal: Dollar Decline and US Grand Strategy after the Crisis. Review of International Political Economy, DOI: $10.1080 / 09692290.2013 .779592$.

Trunkos, J. (2020). Comparing Russian, Chinese and American Soft Power Use: A New Approach. Global Society, DOI: 10.1080/13600826.2020.1848809

Wray, R. (2012). Modern Money Theory. New York: Palgrave MacMillan.

Yaacob, S.E. (2012). Superiority of the gold dinar as currency: study based on the history of Islamic civilization. Islamiyyat, 34(1), 119-129.

Yuning, Z. (2020, May 8). U.S. luxury retailer Neiman Marcus files for bankruptcy amid COVID-19 crisis. Retrieved from ECNS: http://www.ecns.cn/news/economy/2020-05-08/detail-ifzwefvs2285319.shtml 